\title{
Outbreak Investigation and Molecular Detection of Pox Virus Circulating in Sheep and Goats in Selected Districts of West Gojjam and Awi Zones Northwest, Ethiopia
}

\author{
Alemzewud Wondimu' \\ Habtamu Tassew ${ }^{2}$ \\ Esayas Gelaye ${ }^{3}$ \\ Yohannes Hagos ${ }^{4}$ \\ Alebachew Belay ${ }^{3}$ \\ Yechale Teshome ${ }^{2}$ \\ Sam Laiju ${ }^{2}$ \\ Getahun Asebe (iD ${ }^{5}$ \\ 'Debre Markos University, College of \\ Agriculture and Natural Resources, \\ Burie, Ethiopia; ${ }^{2}$ Bahir Dar University, \\ College of Agriculture and Environmental \\ Science, Bahir Dar, Ethiopia; ${ }^{3}$ National \\ Veterinary Institute, Debre Zeit, Ethiopia; \\ ${ }^{4}$ Mekele University, Mekele, Ethiopia; \\ ${ }^{5}$ Gambella University, College of \\ Agriculture and Natural Resource, \\ Gambella, Ethiopia
}

\begin{abstract}
Introduction: Sheep and goat pox virus (SGPV) is a systemic contagious disease causing extreme illness and death in small ruminants.

Methods: A cross-sectional study was conducted in West Gojjam and Awi zone of Amhara national regional state Northwest Ethiopia, from November 2018 to May 2019 with the objective of pox virus outbreak investigation and molecular detections in sheep and goats (shoats). The study included clinical examinations of lesions, laboratory analysis, and questionnaire survey. Study locations were selected randomly when an active outbreak was reported and observed.
\end{abstract}

Results: A total of 485 small ruminants (303 sheep and 182 goats) suspected of shoat pox were examined for the presence of specific skin lesions, 71 (14.64\%) showed pox lesions, 35 (11.55\%) sheep and $36(19.78 \%)$ goats, and 24 (4.95\%) had died. The study revealed highest morbidity rate in Jawie (31.25\%) and Gunagua (14.89\%) districts in goats and sheep, respectively. Lowest morbidity rate was recorded in Dega Damot district in sheep $(6.45 \%)$ and goats $(7.14 \%)$, respectively. The mortality rate was $>1 \%$ in all districts except Dega Damot for both species. From a total of 38 tissue samples, 19 samples were selected based on the geographical distribution. All 19 samples (6 sheep and 13 goats) were found to be positive for goat pox virus based on polymerase chain reaction results. The significant risk factors were free animal movements, age, flock size and composition, body condition, vaccination status, and season. The study showed that in the absence of free movement of animals, the disease was less likely to occur ( $\mathrm{OR}=0.05, \mathrm{CI} 95 \% ; 0.02,0.15$ ).

Conclusion: The disease was found in higher rate during the dry and short rainy season. Sheep were also found to be infected by goat pox virus. The study indicated that there was widespread sheep and goat pox in Northwest Ethiopia.

Keywords: Amhara, epidemiology, PCR, shoat, risk factors

\section{Introduction}

Ethiopia has the largest number of animals in Africa where livestock production makes a paramount economic contribution to agricultural development. Sheep and goats have an estimated population size of 30.697 , and 30.200 respectively. $^{1}$

Even though small ruminants play a considerable role in the Ethiopian national economy, including the study areas, no significant contribution is obtained due to many limiting factors. Small ruminant diseases is the principal challenge that has reduced the growth of livestock by subsiding production and impeding trade
Correspondence: Getahun Asebe Email getahunasebe@gmail.com 
activities. $^{2,3}$ Infectious diseases such as Capripoxviruses are the key, and are most commonly distributed in all regions of Ethiopia. ${ }^{4}$

Sheep and goat (shoat) pox (SGP) is a systemic contagious disease causing extreme illness and death in small ruminants and ${ }^{3}$ an important transboundary and notifiable disease based on World Organization for Animal Health (OIE).$^{5}$ Characteristically, the disease is not seen as commonly in local sheep and goats as compared with exotic breeds. $^{4,5}$

Sheep and goat pox virus (SGPV) is a highly contagious virus causing disease in shoats that belongs to the genus Capripoxvirus (CaPV), subfamily Chordopoxvirinae, and family Poxviridae. Studies show that there is a 96\% nucleotide and amino acid similarity among the sheep pox virus (SPPV), goat pox virus (GTPV), and lumpy skin disease virus (LSDV). In category, the Nigerian, Middle Eastern and Indian strains Capripoxviruses are included in one host strain. However, Capripoxviruses of Kenyan shoat pox virus (KSGPV) and Yemen and Oman pox virus are not host-specific and jointly infect sheep and goats. ${ }^{6}$ Clinically it is common to see skin lesions, fever, conjunctivitis with oculonasal discharge, excessive salivation, and internal organ pox lesions during the infection. The Capripoxviruses are highly contagious. Transmission occurrs via contact of infected and non-infected small ruminants. Shoat pox virus transmission also occurrs through aerosols or respiratory droplets or by direct/indirect contact with lesions or oro-nasal secretions. ${ }^{7}$

Capripoxvirus viral DNA amplification is known as a rapid test, specific to the genus and sensitive for detection of pox disease either before and/or after the development of antibody responses. The common amplification techniques include the conventional polymerase chain reaction (PCR), real-time $\mathrm{PCR}$, and the loop-mediated isothermal amplification (OIE, 2017). For obtaining sufficient genetic material for identification, using conventional PCR methods is very useful for species' identification during subsequent sequence and phylogenetic analysis. ${ }^{8}$

Disease status of a country determines the Capripoxviruses control approach. For instance, pox free nations use quarantine system to prevent the entrance of infected animals. However; endemic countries like Ethiopia places emphasis on immunization strategies to control and avoid the occurrence of shoat mall ruminant pox disease. In our country, wherever small and large ruminants are affected, a live weakened (KSGP-O-180) vaccine strain and combined shoat pox (SGP) and peste des petits ruminants (PPR) vaccines are used for the vaccination of small and large ruminants. Even though the presence of the pox disease in immunized shoats has been frequently described, evidence on the circulating isolates and their relation to the vaccine strain in use is still univariable. ${ }^{9}$ In domestic ruminants, Capripoxviruses are the most economically significant diseases in Africa and Asia. ${ }^{10}$ In Ethiopia, shoat pox is one of the most important diseases of small ruminants next to Peste des petits ruminants (PPR) and Contagious Caprine PleuroPneumonia (CCPP). ${ }^{11}$

In Ethiopia, a total of 57,638 shoats contracted SGPV disease and more than 4.8 million of shoats were at risk in areas where outbreaks occurred. Out of the 57,638 sick small ruminants, 6401 shoats died, with a case fatality rate of $11.11 \%{ }^{12}$

There are no recent studies based on the outbreak investigation and molecular detections of shoat poxvirus infection in small ruminants in outbreak cases of Northwest Amhara. Detections of circulating sheep and goat poxvirus strain have still not been done in the study areas. Molecular detection is a collection of techniques used to analyze biological markers in the genome and proteome and how their cells express their genes as proteins.

\section{Methods \\ Study Area}

This research was conducted in selected districts of West Gojjam zone (Burie, Mecha, Yilmana Densa, Dega Damot, and Sekela) and Awi zones (Banja Shikudad, Gunagua, and Jawie) districts of Northwest, Ethiopia Amhara national regional state, as shown in Figure 1. The subregion is situated between $10.00^{\circ}$ to $14.00^{\circ}$ North latitude and $35.10^{\circ}$ to $38.35^{\circ}$ East longitude. The annual rainfall ranges from $878 \mathrm{~mm}$ to $2100 \mathrm{~mm}$ and the annual minimum and maximum temperature was $22^{\circ} \mathrm{C}$ and $30.7^{\circ} \mathrm{C}$, respectively. The study area encompasses three agro-ecologies namely highlands, midlands, and lowlands. Western Amhara region is characterized by maintenance mixed production system ${ }^{13}$ and ranked as first in its small ruminant population in the Amhara regional states. Approximately 6.6 million sheep and goats are raised in the western Amhara regional state. ${ }^{1}$

\section{Study Populations and Management System}

The study population consisted of small ruminants from eight selected districts and nine rural kebeles that 


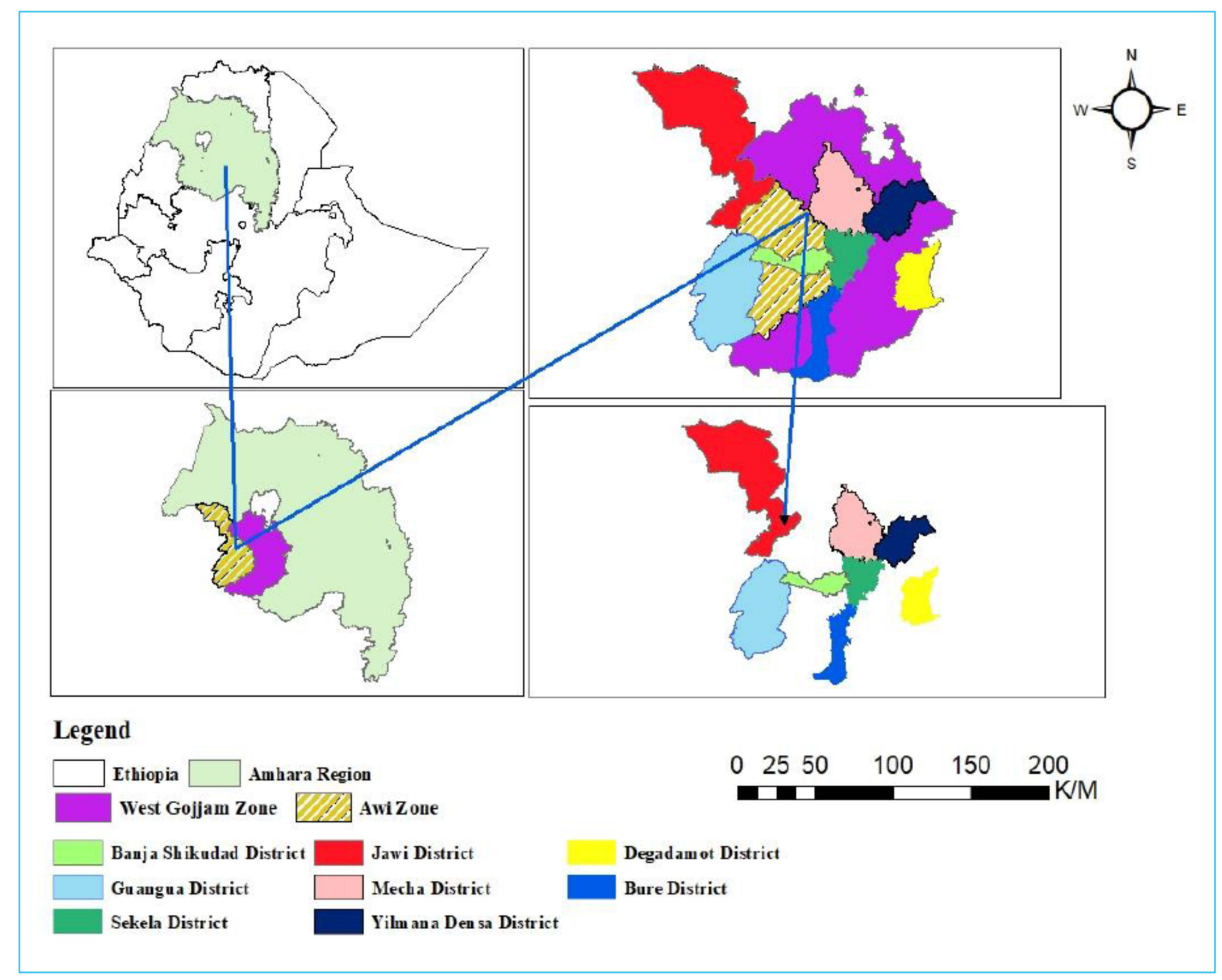

Figure I Map of study areas.

manifested clinical signs of SGPV and those shoats which had close contact with clinically infected small ruminants. The sampling units for the study were local shoats breeds of all ages and both sex groups under an extensive management system by smallholder farmers.

\section{Study Design and Sampling Methods}

An outbreak investigation was done $e^{14}$ from November 2018 to May 2019 in small ruminants showing clinical signs of pox infection and small ruminants which were in close contact with clinically infected shoats.

The districts and sub-districts were selected randomly based on the presence or suspected outbreaks of shoat pox disease and convenience for transportation. From selected districts and rural associations, the flocks and individual small ruminants for examinations were randomly selected based on the existence or suspected diseases and investigated by communicating with zonal head offices, districts, and rural animal health professionals working in veterinary clinics. Whenever we came across a small ruminant pox outbreak or one was reported, an immediate field-level investigation was carried out and animals were closely examined physically and clinically. Samples for skin biopsies were randomly collected in outbreak cases from clinically sick animals (11 sheep and 27 goats) showing suspected Capripoxvirus lesions based on geographical distribution.

\section{Sample Size}

The probability sampling method was applied to detect sheep and goat pox from outbreak cases from eight districts. The sample size was estimated according to a formula by Thrustfiled $^{15}$ with an expected prevalence 
of $50 \%$ and a desired absolute precision of $\pm 5 \%$ that brings the total sample size to 384 . The formula; $n=\frac{z^{2} \mathrm{xpq}}{d^{2}}$ was used to estimate the sample size. To increase the accuracy of the data produced by the survey, we added and sampled an additional $26 \%$, bringing the total to 485 . Hence, during the study period, there were 485 sheep and goats, of these, 303 sheep and 182 goats were clinically examined. From all infected sheep and goats, and also as a cost-effective strategy, a total of 38 tissue samples (11 sheep and 27 goats) were randomly collected from eight different outbreak districts with those small ruminants showing typical signs of pox lesions for molecular detections.

\section{Data Collection}

The current study engaged various outbreak investigation approaches including clinical examinations, laboratory analyses, and questionnaire surveys to acquire the risk factors of sheep and goat pox.

\section{Active Outbreak Investigation and Clinical Examinations}

During outbreak investigation, about 303 sheep and 182 goats (of these 251 unvaccinated sheep and 48 unvaccinated goats) were examined, out of these, 35 sheep and 36 goats showed pox lesions. In each outbreak, physical examination of all parts of the body including the mucous membranes was carried out. The clinical signs observed in infected sheep and goat pox virus was fever, depression, different sized skin nodules, necrotic nodule under the tail and perineum, papules and nodules, lacrimation, and nasal discharge mainly in the young.

\section{Laboratory Analysis}

\section{Sample Collections and Processing}

Samples for skin biopsies were collected randomly in outbreak cases from clinically sick animals (11 sheep and 27 goats) showing suspected Capripoxvirus lesions. About 3 grams of tissue samples were collected aseptically by removing the hairs, using a scalpel blade, under the tail. All the collected specimens were kept separately in sterile universal bottles that contain phosphate buffered saline A (PBSA) (50\%) with $\mathrm{pH}$ value ranges from 7.2 to 7.6 . A drop of antibiotic (pen-strep), a combination of penicillin $\mathrm{G}$, benzathine penicillin $\mathrm{G}$, and dihydrostreptomycin sulphate and a drop of statin to inhibit bacterial and fungal growth respectively. Samples were labeled with an identification number (sample code), species, sex, age, district, and rural kebele and immediately placed in a cold icebox and transported to a regional veterinary laboratory located at Bahir Dar. Then, skin scrapings were stored at -20 degree centigrade until being shipped to the National Veterinary Institute (NVI), Debre Zeit.

All collected skin scrape samples were thawed at $25^{\circ} \mathrm{C}$ and washed three times using sterile 50\% PBSA containing antibiotics such as pen-strep which is a combination of penicillin $\mathrm{G}$, benzathine penicillin $\mathrm{G}$ and dihydrostreptomycin sulphate and statin at a $\mathrm{pH}$ of 7.2 in the BSL II cabinet. Approximately a gram of the thawed specimen was taken from sterilized petri dish using thumb forceps, and then grounded by sterile pestle and mortar after adding $9 \mathrm{~mL}$ of sterile $50 \%$ PBSA. Then the grounded specimens were placed in a sterilized vacutainer tube and centrifugation of mixtures of the tissue was done at $3500 \mathrm{rpm}$ for 10 minutes at $4^{\circ} \mathrm{C}$. About $1 \mathrm{~mL}$ solution was collected, then placed in cryovial tubes, then capped and wrapped with aluminum foil, labeled, and finally preserved at $-20^{\circ} \mathrm{C}$ until dispatching to molecular biology laboratory.

\section{Extraction of Genomic DNA and PCR Amplification}

Genomic DNA extraction was carried out using the manufacturer's instruction using the DNease Blood and Tissue kit (Qiagen, Germany). About $200 \mu \mathrm{L}$ processed supernatant was transferred into a labeled $1.5 \mathrm{~mL}$ Eppendorf tube. Hence, $20 \mu \mathrm{L}$ proteinase $\mathrm{K}$ and $200 \mu \mathrm{L}$ Lysis Buffer (Buffer AL) were added to each and mixed well using vortex. The mixed samples were then incubated at $56^{\circ} \mathrm{C}$ for 30 minutes for enzyme activation and until totally lysed. Hence after, $200 \mu \mathrm{L} 96 \%$ ethanol was used per tube and vortexed to precipitate the extracted DNA. ${ }^{16}$

Conventional PCR was used for amplification of the 30KDa RNA polymerase subunit (RPO30) gene of Capripoxviruses (Mangana-Vougiouka et al, 2000). PCR was done in a total volume of $20 \mu \mathrm{L}$ containing $3 \mu \mathrm{L}$ RNase free water, $2 \mu \mathrm{L}$ forward primer SpGpRNApol-F-5'TCTATGTTCTTGATATGTGGTGGTAG-3' $\quad(5 \mathrm{pm} / \mu \mathrm{L})$ $2 \mu \mathrm{L}$, reverse primer, 5'-AGTGATTAGGTGGTGTATT ATTTTCC-3' $(5 \mathrm{pm} / \mu \mathrm{L})$. IQ super mix $10 \mu \mathrm{L}$ and $3 \mu \mathrm{L}$ template DNA sample. The PCR consisted of an initial denaturation process for 5 minutes at $95^{\circ} \mathrm{C}$, then it was followed by 40 cycles of denaturation process for 30 seconds at $95^{\circ} \mathrm{C}$, an annealing process for 30 seconds at $55^{\circ} \mathrm{C}$, and extension process for 30 seconds at $72^{\circ} \mathrm{C}$, and then a final extension process for 7 minutes at $72^{\circ} \mathrm{C}$. 


\section{Analysis of the PCR Products}

Gel electrophoresis was used for separating the PCR products using 3\% agarose gel. For gel analysis, $10 \mu \mathrm{L}$ of the product was loaded in each gel lane. About 100 bp DNA ladder was loaded (Qiagen, Germany, $\mathrm{GmbH}$ ) and used to determine the fragment sizes. The amplified DNA products were analyzed with a component $4 \mu \mathrm{L}$ gel red loading dye. Then electric power (120 volts) was connected to the gel running tank for 1:20 hours to separate the bands based on the molecular weights of the amplified samples. The gel was then photographed by a gel record system (Biometra) and the data were analyzed using computer software.

\section{Survey}

We used a questionnaire survey to assess the perception and attitudes of domestic small ruminant owners, about the occurrence and frequency of Capripoxvirus diseases in the area. Additionally, the survey included the risk factors of SGP. The questionnaire was done via face-to-face interview with one representative of sheep and goat owners. To determine the participants included in the interview, a $95 \%$ CI was used. ${ }^{17}$

$$
\mathrm{n}=0.25 / \mathrm{SE}^{2}=0.25 /(0.05)^{2}=100
$$

Where: $\mathrm{n}=$ the required interviewed sample size, $\mathrm{SE}=$ Standard Error.

\section{Ethics Statement and Consent to Participate}

This was an activity registered and known to Bahir Dar University College of Agriculture and Environmental Sciences with reference number BTC 465/02/2018 and the date June 11/2018 under the college review committee (IRC). The verbal informed consent was approved by the ethical review committee. All necessary permits were obtained from the concerned government offices respectively from the top to the smallest administrative subdistricts. Following this, the consent of animal owners was obtained to take samples from their animals. After obtaining consent from animal owners orally, tissue samples were collected from the infected domestic small ruminants for disease confirmation. We minimized pain during skin scraping collections and disinfected with $2 \%$ iodine on sample-taking areas. Sample collection, shipping of specimens, and their use were in accordance with NVI laboratory animal use ethics to minimize the spread of the disease.

\section{Statistical Data Analysis}

The questionnaire survey was entered and stored in Excel spreadsheet 2010. The data were screened and coded, then the data were imported to STATA version $13 .{ }^{18}$ The descriptive statistical results were used to determine morbidity, mortality, case-fatality rates, and the frequency of disease occurrences. The potential risk factors were analyzed using univariable logistic regression. Results with p-value less than $\leq 0.05$ during the analysis were reported as statistically significant and the value 1 was not included in the $95 \%$ CI. Multivariable logistic regressions were used to measure the risk factors and to identify the confounding factors.

\section{Results}

\section{Active Outbreak Investigation and Field Clinical Examinations}

In this study, outbreak cases from eight districts were investigated between November 2018 and May 2019. During the outbreak, small ruminants were examined both physically and clinically. The common signs observed in infected sheep and goats were fever ranging from 40 to $42^{\circ} \mathrm{C}$, marked depression, weakness, enlarged lymph nodes, discharge from eyes and nostrils in lambs and kids, lesions on the head region, macula, and papules on the median of the thigh, under the tail and whole body (Figure 2).

Based on the clinical signs, the highest numbers of affected sheep were found in Gunagua district (14.89\%),

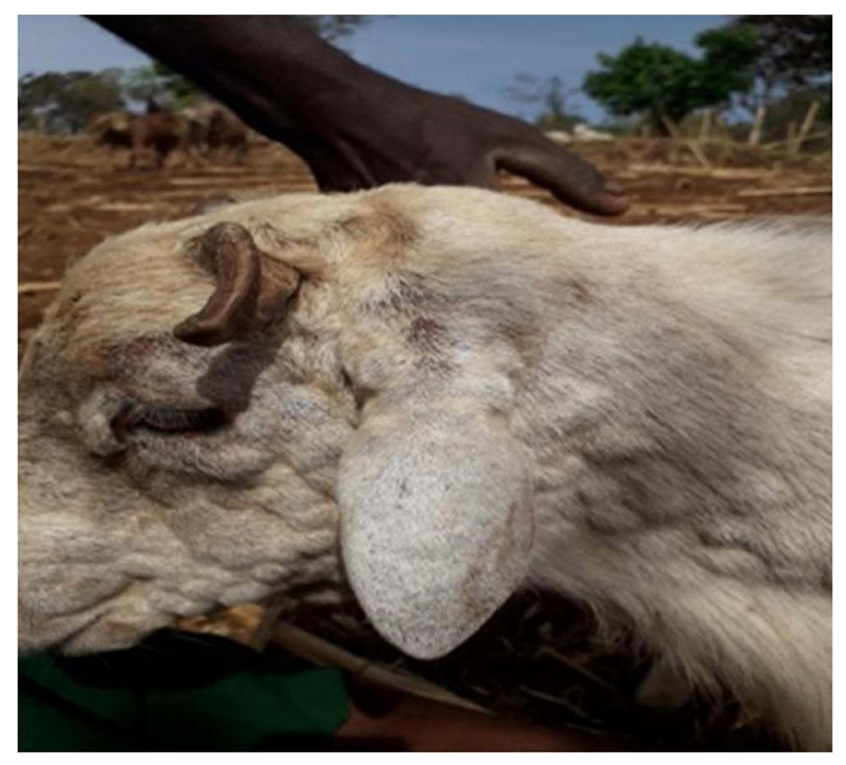

Figure 2 Characteristic pox signs in sheep observed during the study. 
while the lowest number of affected sheep were recorded in Dega Damot district (6.45\%). The highest number $(31.25 \%)$ of goats affected by the poxvirus was found in Jawie district and the lowest numbers of affected goats were observed in Dega Damot district (7.14\%) (Tables 1 and 2).

\section{Molecular Detection of Capripoxvirus}

PCR amplifications indicated that samples collected from those sheep and goats showed typical pox signs, all of the 19 samples processed in NVI for molecular detections tested positive for goat poxviruses by producing an amplicon size of $172 \mathrm{bp}$ (Figures 3 and 4). These indicated that the clinical signs were suggestive of sheep and goat pox.

The procedure was the primers flanking a 26-nucleotide deletion so that the PCR amplification products from SPPV strain (151bp) shorter than GTPV strain (172bp).

\section{Survey}

From a total of 100 individuals subjected to questionnaires, $83 \%(n=100)$ responded that the disease usually occurred frequently every year, $11 \%$ said it occurred every two years, and the remaining $6 \%$ responded that the disease occurred every three years. Furthermore, all $(100 \%)$ responded that all animals shared communal watering points and free grazing.

\section{Risk Factors Associated with the Disease}

About 100 sheep and goat owners (10 in each the seven districts and 30 in Banja district) responded about risk factors for the occurrences of SGP diseases. A total of 11 related potential risk factors were analyzed for their significance with the existence of small ruminant pox (Table 3). Age of small ruminants, vaccination status, herd size and composition, free movement of sheep and goats, and season showed statistically significant association with pox infection $(\mathrm{P} \leq 0.05)$, and 1 was not included in the CI (Tables 3 and 4).

The current findings indicated that of seven significant factors in univariable logistic regressions, only three were significant in multivariable regressions which included vaccination status, flock size, and season. The disease rate was $10.5 \%$ when the flock size ranged from 10 to 19 and $80.5 \%$ as the flock size increased beyond 20 as compared to the flock size lower than 10 . The study revealed that the highest seasonal existence of pox was $11.6 \%$ higher in dry season when compared to the rainy seasons, as indicated in Table 3. The multiple logistic regressions revealed that vaccinated sheep and goats were $86.8 \%$ more protected than the nonvaccinated small ruminants (Tables 3 and 4).

\section{Discussion}

Sheep and goat pox (SGP) is a highly transmissible viral disease that results in an extensive loss in the production and productivity of shoats in Ethiopia. Regarding the status of the disease in Ethiopia, SGP was endemic in almost all the regions of Ethiopia. ${ }^{12}$ This study was based on a cross sectional survey in various districts, and different approaches were adopted for molecular detections of the disease. During the study, nine natural outbreak cases of Capripoxvirus occurred in the study area between November 2018 and May 2019. To our knowledge, this is the first molecular detection evidence of sheep and goat pox outbreak cases in Amhara national regional state. The most remarkable feature of these outbreaks was their species non-host specificity. SPPV and GTPV could not be distinguished by serological tests due to close antigenic relationship. ${ }^{19,20}$ Due to the low

Table I Pox Frequency in Goats in West Gojjam and Awi Zone

\begin{tabular}{|l|l|l|l|l|l|l|}
\hline District & $\begin{array}{l}\text { No. of Individual Goats } \\
\text { Examined }\end{array}$ & $\begin{array}{l}\text { No. of Goats } \\
\text { Affected }\end{array}$ & $\begin{array}{l}\text { Number of } \\
\text { Deaths }\end{array}$ & Morbidity & $\begin{array}{l}\text { Mortality } \\
\text { Case Fatality } \\
\text { Rate }\end{array}$ \\
\hline Burie & 12 & 3 & 1 & $25 \%$ & $8.33 \%$ & $33.33 \%$ \\
Mecha & 21 & 5 & 2 & $23.80 \%$ & $9.52 \%$ & $40 \%$ \\
Yilmana Densa & 12 & 3 & 1 & $25 \%$ & $8.33 \%$ & $33.33 \%$ \\
Sekela & 15 & 2 & 1 & $13.33 \%$ & $6.66 \%$ & $50 \%$ \\
Dega Damot & 28 & 2 & 0 & $7.14 \%$ & $0 \%$ & $0 \%$ \\
Banja & 46 & 7 & 4 & $15.21 \%$ & $8.69 \%$ & $57.12 \%$ \\
Guangua & 32 & 9 & 2 & $28.13 \%$ & $6.25 \%$ & $22.22 \%$ \\
Jawie & 16 & 5 & 2 & $31.25 \%$ & $12.5 \%$ & $40 \%$ \\
Total & 182 & 36 & 13 & $19.78 \%$ & $7.4 \%$ & $36.11 \%$ \\
\hline
\end{tabular}


Table 2 Pox Frequency in Sheep in West Gojjam and Awi Zone

\begin{tabular}{|l|l|l|l|l|l|l|}
\hline District & $\begin{array}{l}\text { No. of Individual Sheep } \\
\text { Examined }\end{array}$ & $\begin{array}{l}\text { No. of Affected } \\
\text { Sheep }\end{array}$ & $\begin{array}{l}\text { Number of } \\
\text { Deaths }\end{array}$ & Morbidity & Mortality & $\begin{array}{l}\text { Case Fatality } \\
\text { Rate }\end{array}$ \\
\hline Yilmana Densa & 21 & 2 & 1 & $9.52 \%$ & $4.76 \%$ & $50 \%$ \\
Dega Damot & 31 & 2 & 0 & $6.45 \%$ & $0 \%$ & $0 \%$ \\
Banja & 204 & 24 & 8 & $11.76 \%$ & $3.92 \%$ & $33.33 \%$ \\
Guangua & 47 & 7 & 2 & $14.89 \%$ & $7.14 \%$ & $28.56 \%$ \\
Total & 303 & 35 & 11 & $11.55 \%$ & $3.63 \%$ & $31.43 \%$ \\
\hline
\end{tabular}

sensitivity and specificity, the serological tests were replaced by PCR.

In this study, a total of $71(14.64 \%)$ shoats out of a population of 485 were affected with a morbidity rate of almost $14.64 \%$. Clinical signs seen in these shoats include nodules, papules on different thin or hairless areas of the body. These clinical findings were consistent with those of Achour et $\mathrm{al}^{21}$ in Algeria, Singh et $\mathrm{al}^{22}$ in India, Chanie ${ }^{23}$ in Ethiopia.

The highest morbidity was recorded in Guangua (14.89\%) and Jawi (31.25\%) districts in sheep and goats respectively, that could be associated with a lack of strategic vaccinations. A questionnaire-based survey collected from rural association veterinary professions, districts, and zonal head offices indicated there were no vaccination practices in the two districts. Additionally, in both districts, because of the warm climate, there was presence of biting flies that favor transmission of pox diseases, which is in line with Rodistits et $\mathrm{al}^{24}$ who stated that vectors with large mouthparts and their frequent feeding habits are the basic factors favoring mechanical transmission.

Furthermore, in both districts, due to the geographical location, there are several illegal small ruminant movements by local traders from nearby markets of Dibate, Gelgel Beles, and Manbuk districts in the Metekel zone, extensive grazing and movement patterns of small ruminants in the districts as well as the variations in the number of affected sheep and goat between the districts. This work was in agreement with the work of Domenech et $\mathrm{al}^{25}$ who stated that the spread of Capripoxvirus into new areas is predominantly associated with the increase of illegal animal movement through trade and also, Babiuk et $\mathrm{al}^{26}$ who reported that poor quarantine measures and trade of live animals across the border may lead to further spread of the disease.

In Dega Damot district, the lowest morbidity and mortality rates both in sheep and goats could be associated with strategic vaccinations of both live attenuated vaccine strain and combined SGP and PPR vaccines for immunization of both small ruminants.

A higher morbidity rate $(19.78 \%$ in goats and $11.55 \%$ in sheep) in the current study was found compared to previously reported results that was $10.34 \%$ in sheep and $12.88 \%$ in goats respectively in Adama area of Ethiopia and 9.5\% in sheep and $12.9 \%$ in goats in Dibate districts Benishangul Gumuz regional state of Ethiopia. ${ }^{27,28}$ This could possibly be due to common free grazing and watering of small ruminants as well as free movements of small ruminants by illegal local traders. Traditional forms of animal husbandry practices increase disease transmission. ${ }^{29}$ However, the current morbidity status was lower than that reported by Molla et $\mathrm{al}^{30}$ both in sheep and goats in Gamo Gofa zone and Chanie $(2011)^{23}$ in sheep in Northwest Ethiopia. This could be due to the fact that animals in endemic areas develop lifelong immunity after recovery. Sheep and goats in endemic areas were more resistant due to previous infection or vaccination. ${ }^{31}$

This study also indicated lower morbidity and mortality rates than previously reported by Babiuk et al, ${ }^{32}$ with a $60 \%$ morbidity and approximately $45 \%$ mortality rate in Vietnam goats. This could be because European sheep and goat breeds are very susceptible to Capripoxvirus, because of the possibility of wildlife spill-over to domestic small ruminants populations, mortality rates could reach up to $100 \%$ as compared to local Dangela, Washera, and Farta breeds of sheep and Gumuz, Agew and Begia-Medir breeds of goats in the study areas. ${ }^{33,34}$

The spread of the disease in Banja Shikudad, Guangua, and Jawie districts followed the recurrence of SGP in the nearby districts of Dibate. ${ }^{27}$ Those districts are connected with the main road of Guangua and Banja Shikudad districts through which there was the movement of a large number of small ruminants. Accordingly, unlawful trading of shoats across the border, along with the movement of shoats, those from affected flocks and borders of the nearby Benishangul Gumuz regional state to different nearby districts of Awi zones related to traditional forms of husbandry practices were believed as contributors to the outbreak. ${ }^{29}$ 


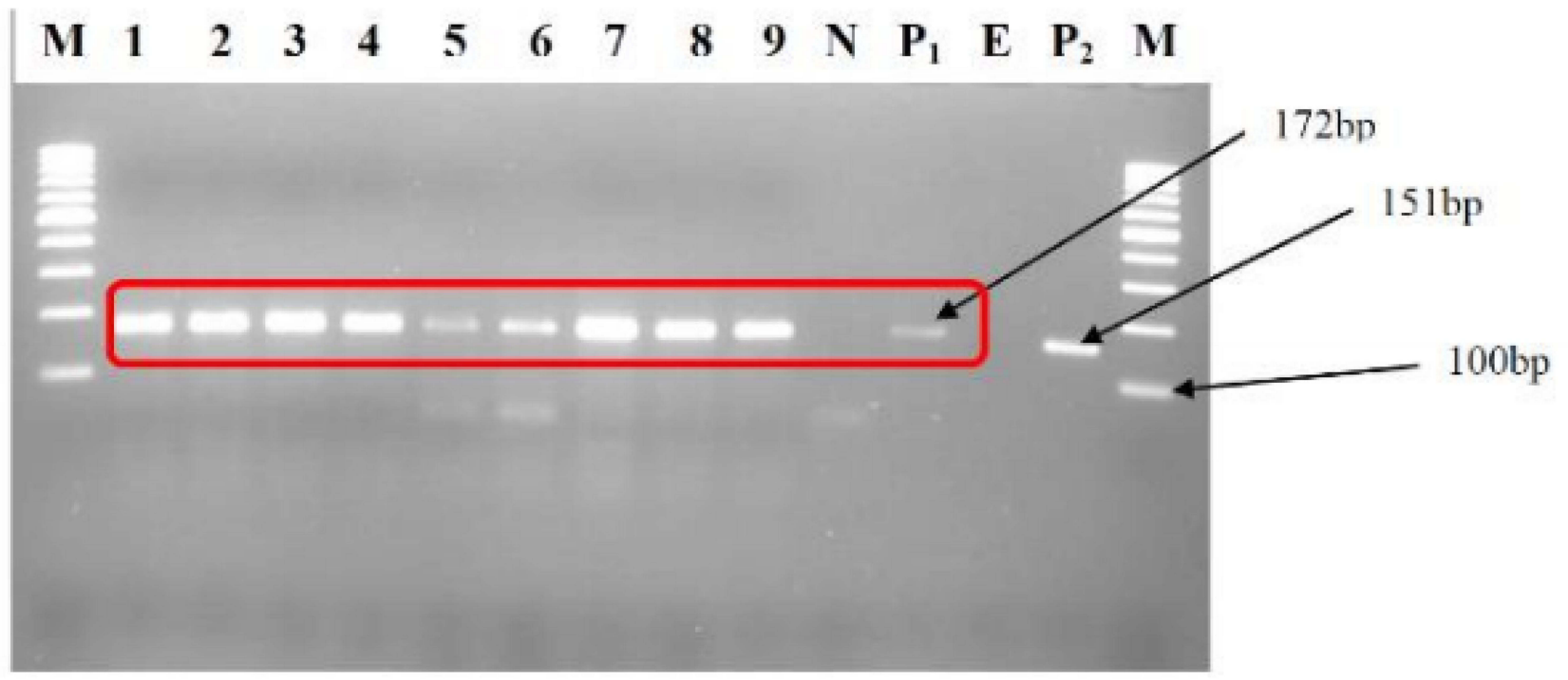

Lane M: DNA ladder /Molecular marker (100bp)

Lane 1, 2 and 4 = Samples collected from goat species in Dega Damot district positive for goat pox virus

Lane 3, 5 and $6=$ Samples collected from goat species in Jawie district positive for goat pox virus

Lane 7 and 8= Samples collected from goat species in Yilmana Densa district positive for goat pox virus

Lane $9=$ Sample collected from goat species in Sekela district positive for goat pox virus

Lane N: negative template control for goat pox

Lane P1: Got pox positive control (172 bp)

Lane P2: sheep pox

Figure 3 Conventional PCR to differentiate Capripoxvirus homolog of the Dega Damot (Lanes I, 2, and 4), Jawie (Lanes 3, 5, and 6), Yilmana Densa (Lanes 7, and 8), and Sekela (Lane 9) districts (from I-9).

The conventional PCR findings revealed that samples collected and processed from both shoats in various districts were detected as goat pox virus with amplicon size of $172 \mathrm{bp}$; whereas sheep pox virus was not identified even from a single specimen, which is in agreement with previous reports. ${ }^{17,35}$ The authors stated that the strain isolated by conventional PCR in both species was goat pox virus, consistent with other studies. ${ }^{27,36}$ The strains of Capripoxvirus causing disease in shoats are not host-specific and may either affect both or one species, which contradicts ${ }^{10,26,37}$ who stated that Capripoxvirus strains isolated were commonly categorized and labeled based on the host from which the virus was detected and shoat pox host-specific.
The survey from this study indicated that the majority of the respondents $(83 \%)(n=100)$ had previously experienced sheep and goat pox disease in their herds. This was lower (96\%) than that reported by Assefa et $\mathrm{al}^{36}$ and (95\%) Kebede et $\mathrm{al}^{27}$ which they locally called "Fenetata".

This finding revealed that sheep and goats were equally susceptible to goat pox virus and it was only goat pox virus causing pox disease both in sheep and goat population with higher severity in goats, in agreement with previous reports. ${ }^{38}$ Statistically insignificant sensitivity difference to pox virus was observed between sheep and goats, as stated by Heine et $\mathrm{al}^{39}$ where Capripoxvirus was not considered as host-specific and the majority of strains 


\section{$\begin{array}{llllllllllllllll}M & 10 & 11 & 12 & 13 & 14 & 15 & 16 & 17 & 18 & 19 & \mathrm{~N}_{1} & \mathrm{P}_{2} & \mathrm{M}\end{array}$}

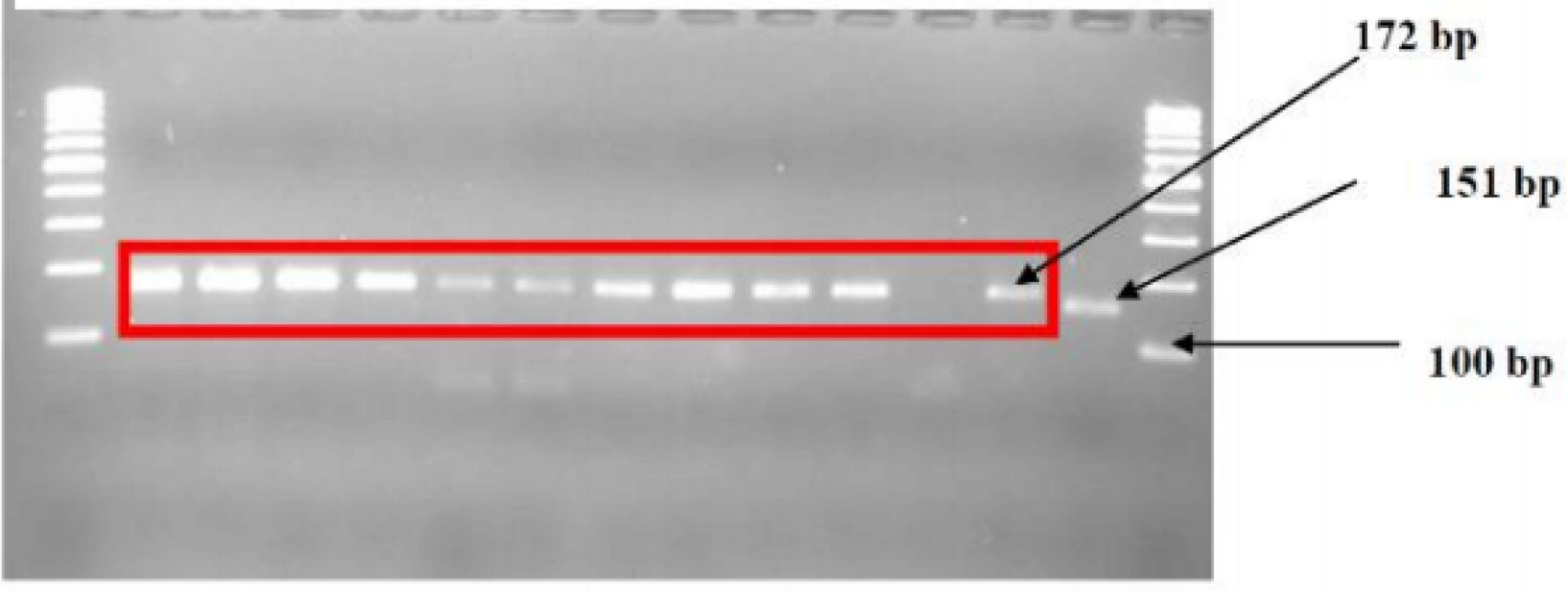

\section{Lane M: DNA ladder /Molecular marker (100bp)}

Lane 10 to 12=Samples collected from goat species in Banja district positive for goat pox virus

Lane 13 = Sample collected from goat species in Burie district positive for goat pox virus

Lane 14 to 17 =Samples collected from sheep species in Guangua district positive for goat pox virus

Lane 18 and $19=$ Samples collected from sheep species in Banja Shikudad district positive for goat pox virus

Lane N: negative template control for goat pox

Lane P1: Got pox positive control (172 bp)

Lane P2: sheep pox

Figure 4 Conventional PCR to differentiate Capripoxvirus homolog of the Banja (Lanes I0, and I2), Burie (Lane I3), Guangua (Lanes I4, and I7), Banja Shikudad (Lanes I8, and 19) districts (from 10-19).

cause disease in both sheep and goats, which is contrary to Assefa et $\mathrm{al}^{36}$ who stated that the disease is more important in sheep due to genetic differences.

In this study, even though all ages were affected, young age groups were (OR) 3.87 times more affected than adults in both species with CI 1.5-9.60 and P-value 0.003 . This could be due to less climatic stress in adults, the fact that recovered animals developed lifelong immunity, and the immune status of the animals. ${ }^{27}$

This finding showed that both sexes were equally affected by Capripoxvirus, but the diseases were more severe in female sheep and goats. This could be due to the female small ruminant's physiology relating to pregnancy and lactation which could result in a poor immune system compared to male sheep and goats. ${ }^{27}$

The current study revealed that sheep and goats of all body conditions were affected by the diseases. However, medium body condition sheep and goats were less likely to be affected by the diseases, as compared to poor body condition $(\mathrm{OR}=0.11$, CI 95\%; 0.02, 0.49).

In the absence of free movement of animals, the diseases were less likely to occur ( $\mathrm{OR}=0.05$; CI 95\%, 0.02, 0.15) and in the absence of vaccination small ruminants were 
Table 3 Analyses of Risk Factors for Small Ruminant Pox in Univariable Logistic Regression

\begin{tabular}{|c|c|c|c|}
\hline Risk Factors & No. of Respondents & OR 95\% Cl & P-value \\
\hline \multicolumn{4}{|l|}{ Species } \\
\hline Sheep & $48(48 \%)$ & 1 & - \\
\hline Goat & $52(52 \%)$ & $\mathrm{I} .02(0.43,2.4 \mathrm{I})$ & 0.972 \\
\hline \multicolumn{4}{|l|}{ Sex } \\
\hline Male & $43(43 \%)$ & 1 & - \\
\hline Female & $57(57 \%)$ & I.II $(0.47,2.65)$ & 0.814 \\
\hline \multicolumn{4}{|l|}{ Age } \\
\hline Young & $64(64 \%)$ & $3.87(1.5,9.60)$ & $0.003^{* *}$ \\
\hline Adult & $36(36 \%)$ & 1 & - \\
\hline \multicolumn{4}{|l|}{ Body condition } \\
\hline Poor & $83(83 \%)$ & I & - \\
\hline Medium & $9(9 \%)$ & $0.11(0.02,0.49)$ & $0.004 * *$ \\
\hline Good & $8(8 \%)$ & 1 & - \\
\hline \multicolumn{4}{|l|}{ Vaccination status } \\
\hline Not vaccinated & $74(74 \%)$ & 1 & - \\
\hline Vaccinated & $26(26 \%)$ & $0.01(0.00,0.05)$ & $0.000 * *$ \\
\hline \multicolumn{4}{|l|}{ Flock size } \\
\hline$<10$ & $9(9 \%)$ & 1 & - \\
\hline $10-19$ & $38(38 \%)$ & $11.08(1.2,101.68)$ & $0.033^{* *}$ \\
\hline $20-30$ & $53(53 \%)$ & $35.7(3.95,322.90)$ & $0.001 * *$ \\
\hline \multicolumn{4}{|l|}{ Flock composition } \\
\hline Sheep only & $24(24 \%)$ & I & - \\
\hline Goat only & $33(33 \%)$ & $58.90(10.38,334.37)$ & $0.000 * *$ \\
\hline Sheep and goats & $43(43 \%)$ & $16.63(4.77,57.98)$ & $0.000^{* *}$ \\
\hline \multicolumn{4}{|l|}{ Sources of outbreak } \\
\hline Common point & $2 \mathrm{I}(2 \mathrm{I} \%)$ & 1 & - \\
\hline Introduction of new animals & $79(79 \%)$ & I.II $(0.47,2.65)$ & - \\
\hline \multicolumn{4}{|l|}{ Free movement } \\
\hline Present & $75(75 \%)$ & 1 & - \\
\hline Absent & $25(25 \%)$ & $0.05(0.02,0.15)$ & $0.000 * *$ \\
\hline \multicolumn{4}{|l|}{ Agro ecology } \\
\hline Highland & $55(55 \%)$ & 1 & - \\
\hline Midland & $33(33 \%)$ & $\mathrm{I} .52(0.55,4.2 \mathrm{I})$ & 0.417 \\
\hline Lowland & $12(12 \%)$ & $0.41(0.11,1.46)$ & 0.083 \\
\hline \multicolumn{4}{|l|}{ Outbreak seasons } \\
\hline Dry & $72(72 \%)$ & $3.8(1.56,9.60)$ & $0.003^{* *}$ \\
\hline Rainy & $28(28 \%)$ & 1 & - \\
\hline
\end{tabular}

Notes: Risk factors considered significant when $\mathrm{Cl}$ did not include I and P-value $\leq 5 \%$. **Statistically significant.

more affected $(\mathrm{OR}=0.01$, CI $95 \% ; 0.00,0.05)$. Thus, unlawful trading and movement of shoats across the border from affected flocks and absence of vaccinations were believed to be contributors to the outbreak of pox virus. $^{29,40,41}$
This study showed that the disease rate in dry seasons was (OR) 3.8 times higher with CI 1.56-9.60 and P-value 0.003 , especially from December to February and from February to May. This might be associated with the free movement of small ruminants in the market from other 
Table 4 Analysis of Host and Management-Related Risk Factors for Small Ruminant Pox in Multiple Logistic Regressions

\begin{tabular}{|c|c|c|c|}
\hline Risk Factors & No. of Small Ruminants & OR 95\% Cl & P-value \\
\hline \multicolumn{4}{|l|}{ Species } \\
\hline Sheep & $48(48 \%)$ & - & - \\
\hline Goat & $52(52 \%)$ & - & - \\
\hline \multicolumn{4}{|l|}{ Age } \\
\hline Young & $64(64 \%)$ & $2.4(0.81,7.32)$ & 0.114 \\
\hline Adult & $36(36 \%)$ & $\mathrm{I}$ & - \\
\hline \multicolumn{4}{|l|}{ Body condition } \\
\hline Poor & $83(83 \%)$ & - & - \\
\hline Medium & $9(9 \%)$ & - & - \\
\hline Good & $8(8 \%)$ & - & - \\
\hline \multicolumn{4}{|l|}{ Vaccination status } \\
\hline Not vaccinated & $74(74 \%)$ & I & - \\
\hline Vaccinated & $26(26 \%)$ & 86.8(20.09I, 375.76I) & $0.000 * *$ \\
\hline \multicolumn{4}{|l|}{ Flock size } \\
\hline$<10$ & $9(9 \%)$ & 1 & - \\
\hline $10-19$ & $38(38 \%)$ & $10.5(1.03,107.26)$ & 0.047 \\
\hline $20-30$ & $53(53 \%)$ & $80.5(6.66,974.42)$ & $0.00 I^{* *}$ \\
\hline \multicolumn{4}{|l|}{ Flock composition } \\
\hline Sheep only & $24(24 \%)$ & - & - \\
\hline Goat only & $33(33 \%)$ & - & - \\
\hline Sheep and goats & $43(43 \%)$ & & \\
\hline \multicolumn{4}{|l|}{ Sources of outbreak } \\
\hline Common point & $21(21 \%)$ & - & - \\
\hline Introduction of new animals & $79(79 \%)$ & - & - \\
\hline \multicolumn{4}{|l|}{ Free movement } \\
\hline Present & $75(75 \%)$ & - & - \\
\hline Absent & $25(25 \%)$ & - & - \\
\hline \multicolumn{4}{|l|}{ Agro ecology } \\
\hline Highland & $55(55 \%)$ & - & - \\
\hline Midland & $33(33 \%)$ & - & - \\
\hline Lowland & $12(12 \%)$ & - & - \\
\hline \multicolumn{4}{|l|}{ Outbreak seasons } \\
\hline Dry & $72(72 \%)$ & II.6(2.97, 45.82) & $0.000^{* *}$ \\
\hline Rainy & $28(28 \%)$ & 1 & - \\
\hline
\end{tabular}

Notes: Risk factors considered significant when $\mathrm{Cl}$ did not include I and P-value $\leq 5 \%$. **Statistically significant.

infected areas by illegal local traders which favors transmission of the disease, which is in agreement with the previous studies. ${ }^{4,42}$ Those studies described outbreaks that occurred in short rainy and dry seasons, and peak outbreaks followed in March but disagreed with the reports of Chanie $(2011)^{23}$ who stated higher outbreaks occurred during rainy seasons in the form of more severe cases. Additionally, the diseases in dry seasons might be associated with scarcity in feed supplies that may cause stress predisposing the sheep and goats to pox infection. ${ }^{43}$

In general, the present study revealed that the disease rate was higher (OR 11.08) with CI 1.2-101.68 and P-value 0.033 when the flock size increased from 10 to 19 and 35.7 times higher with CI 3.97-322.900 and P-value 0.001 when the flock size was greater than 20 individual animals, which is in agreement with the 
previous reports ${ }^{27}$ which revealed that large flock size and herding of sheep and goats together predispose to Capripoxvirus. This finding also indicated that the disease rate was (OR) 58.90 times higher in goat herds and (OR) 16.63 in sheep and goat herds with CI 4.77-57.98 and P-value 0.000 in comparison to sheep flocks only. This could be because the virus isolated was the goat pox virus which prefers homologous hosts.

\section{Limitations of the Study}

In this study, we did not conduct sequencing of the PCR amplification result which would have given a better clue in further explanation of the sheep and goat pox virus circulating in the area, which would have better explained and helped in vaccine application for prevention and control of the disease.

\section{Conclusion}

Shoat pox is a common infection in domestic small ruminants in the study areas with outbreak reports causing huge economic losses to small ruminant farming societies, resulting in high morbidity and mortality. The study indicated that there was widespread sheep and goat pox in Northwest Ethiopia. This spread could occur through the illegal trade of infected animals and also because of a lack of strategic vaccinations. Based on conventional PCR, targeting RPO30 genes to detect the pox virus circulating in sheep and goats showed that only goat pox virus was found in sheep and goats, disproving the host specificity classification of $\mathrm{CaPV}$, so reconsideration of the host specificity of pox diseases is essential. This finding revealed that Capripoxvirus is more prevalent in dry and short rainy seasons and common young shoats. The frequency of Capripoxvirus was high in goat species as compared to sheep and also commonly seen in unvaccinated sheep and goats. The disease is also highly important in large herd size and mixed herd size of sheep and goats. Hence, strict prevention and control should be implemented accompanied by continuous tracing and surveillance strategies. Furthermore, comprehensive studies should be conducted on the prevalence of the diseases, epidemiology of the disease outbreaks, host specificity of CaPV, and there should be further sequencing of PCR products.

\section{Acknowledgments}

We would like to thank West Gojjam and Awi zones Livestock and Fishery Bureau staff. Our gratitude also goes to the staff of specific districts of the Burie, Mecha, Yilmana Densa, Dega Damot, Sekela, Banja Shikudad, Gunagua, and Jawie districts livestock Office, shoat owners, and data collectors for their unreserved countinous support. We would like to pass our gratitude to NVI staff members namely Getaw Derese and Hawa Mohammed for their excellent technical work.

\section{Funding}

This study was financially supported by the National Veterinary Institute for conducting molecular laboratory.

\section{Disclosure}

The authors report no conflicts of interest in this work.

\section{References}

1. CSA. Central statistical agency federal democratic republic of Ethiopia agricultural sample survey report on livestock and livestock characteristics Addis Ababa, Ethiopia. CSA Bulletin2013;2:2012-2013.

2. Jilo K, Abdela N, Adem A. Insufficient veterinary service as a major constraints in pastoral area of Ethiopia: a review. Jbio, Agri Heal. 2016;6:94-101.

3. Yune N, Abdela N. Epidemiology and economic importance of sheep and goat pox: a review on past and current aspects. School of Veterinary Medicine, College of Agriculture and Veterinary Medicine, Jimma University, Jimma. $J$ Vet Sci Technol. 2017;8:2157-7579. doi:10.4172/2157-7579.1000430

4. Tesgera T, Jing Z, Jia H, Chen G, He XB. A review on sheep pox and goat pox: insight of epidemiology, diagnosis, treatment and control measures in Ethiopia. J Infect Dis Epidemiol. 2018;4:4-5.

5. Madhavan A, Venkatesan G, Kumar A. Capripoxviruses of small ruminants: current updates and future perspectives. Asian J Anim Vet $A d v$. 2016;11:3-5. doi:10.3923/ajava.2016.757.770

6. Yan XM, Chu YF, Wu GH, et al. An outbreak of sheep pox associated with goat poxvirus in Gansu province of China. Vet Microbiol. 2012;156:425-428. doi:10.1016/j.vetmic.2011.11.015

7. Balinsky CA, Delhon G, Simoliga G, et al. Rapid preclinical detection of sheep pox virus by real -time PCR assay. J Clin Microbiol. 2008;46:438-442. doi:10.1128/JCM.01953-07

8. Le Goff C, Lamien CE, Fakhfafh E, et al. Capripoxvirus G-proteincoupled chemokine receptor, a host-range gene suitable for virus-animal origin discrimination. J Gen Virol. 2009;90:67-77. doi:10.1099/vir.0.010686-0

9. Gelaye E, Belay A, Ayelet G, Jenberie S, Yami M. Capripox disease in Ethiopia: genetic differences between field isolates and vaccine strain and implications for vaccination failure. Antivir Res. 2015;119:28-35. doi:10.1016/j.antiviral.2015.04.008

10. Bhanuprakash V, Indrani BK, Hosamani M, Singh RK. The current status of sheep pox disease. Comp Immunol Microbiol Infect Dis. 2006;29:27-60. doi:10.1016/j.cimid.2005.12.001

11. Tsegaye D, Belay B, Haile A. Prevalence of major goat diseases and mortality of goat in Daro-Labu district of West Hararghe, Eastern Ethiopia. J Sci Inn Res. 2013;2:665-672.

12. Kenubih A, Mammo B, Terefe G, Fentahun T. Assessment of the impact of sheep and goat pox lesions on skin quality in selected ware houses of central Ethiopia. University of Gondar, College of Veterinary Medicine and Animal Sciences, Gondar, Ethiopia. Veterinary Medicine. Res Reports Dove Press. 2021;12:203.

13. Adugna A. Amhara Demography and Health, Bulletin; 2014. Available from: http://www.ethiodemographyandhealth.org/. Accessed August 11, 2019.

14. Thrusfield M. Veterinary Epidemiology. 3rd ed. Blackwell science Ltd; 2005 . 
15. Thrustfield M. Veterinary Epidemiology. 3rd ed. Blackwell Publishing Ltd; 2007. Available from: www.blackwellpublishing. com. Accessed November 8, 2021.

16. Saloum De Neves Manta F, Leal-Calvo T, Justo S, et al. Ultrasensitive detection of Mycobacterium leprae: DNA extraction and PCR assays. PLoS Negl Trop Dis. 2020. doi:10.1371/journal. pntd.0008325

17. Lamien C, Goff CL, Silber R, et al. Use of the Capripoxvirus homologue of vaccinia virus $30 \mathrm{kDa}$ RNA polymerase subunit (RPO30) gene as a novel diagnostic and genotyping target: development of a classical PCR method to differentiate goat poxvirus from sheep poxvirus. Vet Microbiol. 2011;21:30-39. doi:10.1016/j. vetmic. 2010.09 .038

18. Stata. Statistical data analysis. Stata version 12.0 special Edition. Stata Corp 4905 Lakeway Drive, College Station, Texas 77845 USA. 800 STAYA - PC; 2012.

19. Zeedan G, Allam A, Nasr S, Aballhamed A. Evaluation the efficacy of Egyptian propolis against parapox viruses by production of IFN-, TNF-and immunoglobulin in experimental rat. World Appl Sci J. 2014;31:199-207. doi:10.5829/idosi.wasj.2014.31.02.

20. Shehbaz H, Hassan I. Phylogenetic analysis of sheep pox virus isolates based on P32 gene in Iraq. $J$ Entomol Zool Stud. 2017;5:704-708.

21. Achour HA, Bouguedour R. Epidemiology of sheep pox in Algeria. Rev Sci Tech off Int Epiz. 1999;18(3):606-617. doi:10.20506/ rst.18.3.1180

22. Singh R, Chandra D, Singh KP, Hosamani M, Singh RK, Chauhan RS. Epidemiological investigation of sheep pox outbreaks in Rajasthan. Indian JVet Patholo. 2007;31:712-715.

23. Chanie M. Clinical and histopathological study of sheep pox in Ethiopia. Inter J Natur Sci. 2011;1:8-92.

24. Radostits OM, Gay CC, Hinchcliff KW, Constable PD. A Textbook of the Diseases of Cattle, Horses, Sheep, Pigs and Goats. 10th ed. Saunders Elsiveire; 2006.

25. Domenech J, Lubroth J, Eddi C, Martin V, Roger F. Regional and international approaches on prevention and control of animal transbound. Emerg Dis Ann NY Acad Sci. 2006;1081:90-107. doi:10.1196/annals.1373.010

26. Babiuk S, Bowden TR, Boyle DB, Wallace DB, Kitching RP. Capripoxviruses: an emerging worldwide threat to sheep, goats and cattle. Transbound Emerg Dis. 2008;55:263-272. doi:10.1111/j.18651682.2008.01043.x

27. Kebede A, Haile Mariam E, Dugassa J. Prevalence of common skin diseases of small ruminants in Dibate district Metekel zone Benishangul Gumuz Regional State Northwestern Ethiopia. Multidiscip J Adv Vet Sci. 2018;2:2-3.

28. Hailu Y, Nesanet B, Ayana D. Part II: prevalences of major skin diseases in cattle, sheep and goats at Adama Veterinary Clinic, Oromia regional state, Ethiopia. Rev Med Vet (Toulouse). 2008;159 (8):455-461.
29. Sheikh AM, Mohammed EH, Babiker HA, Abdel-Wahid SA. Alteration in some epidemiological patterns and virus heterogeneity recently observed in sheep pox outbreaks in Sudan. Veterinaski Arh. 2004; 74:341-350.

30. Molla B, Haile H, Alemu S. Prevalence and risk factors associated to skin diseases in small ruminants in Gamo Gofa zone, Southwestern Ethiopia. J Vet Med Anim Heal. 2017;9(8):228-234.

31. Castro AE, Heuschelc WP. Veterinary Diagnostic Virology MosbyYear Book. Inc.I.J.S.A.; 1992.

32. Babiuk S, Bowden TR, Parkyn G, et al. Yemen and Vietnam Capripoxviruses demonstrate a distinct host preference for goats compared with sheep. $J$ Genes Virol. 2009;90:105-114. doi:10.1099/vir.0.004507-0

33. Radostits OM, Gay $\mathrm{C}$, Hinchcliff $\mathrm{KW}$. Veterinary Medicine. Saunders; 2006.

34. Mirzaie K, Mohammad SB, Bokaie S. A review of sheep pox and goat pox: perspective of their control and eradication in Iran. $J A d v$ Vet Anim Res. 2015;2(4):373-381.

35. Kitching RP. Vaccines for lumpy skin disease, sheep pox and goat pox. Dev Biol. 2003;114:161-167.

36. Assefa A, Weilnda B, Abunna F. Isolation and characterization of pox virus circulating in sheep and goats from outbreak cases of Adea Berga district, West Shoa Zone, Oromia, Ethiopia. Int J Curr Res Aca Rev. 2019;7(6):1-7.

37. Beard PM, Suga S, Bazarragchaa E, et al. A description of two outbreaks of Capripoxvirus disease in Mongolia. Vet Microbiol. 2010;142:427-431. doi:10.1016/j.vetmic.2009.10.018

38. Bidjeh KK, Ganda C, Diguimbaye I. Goat smallpox in Chad: study of the pathogeny of the virus in sheep and goats. Rev Elev Med Vet Pays Trop. 1991;44(1):33-36. doi:10.19182/remvt.9211

39. Heine HG, Stevens MP, Foord AJ, Boyle DB. A Capripoxvirus detection PCR and antibody ELISA based on the major antigen P32 the homolog of the vaccinia virus H3L gene. J Immunol Methods. 1999;227:187-196. doi:10.1016/S0022-1759(99)00072-1

40. Hussein M, El-Sadi HI, Zangana IK, El-Attar MY, Al-Bana AS. Clinical, pathological and virological studies on goat pox in Mosul, Iraq. Vet Med J Giza. 1989;37:65-76.

41. Mahmoud MA, Khafagi MH. Detection, identification, and differentiation of sheep pox virus and goat pox virus from clinical cases in Giza Governorate, Egypt. $J$ Vet World. 2016;9(12):1445-1449. doi:10.14202/vetworld.2016.1445-1449

42. Bhanuprakash V, Moorthy AR, Krishnappa G, Gowda RN, Indrani BK. An epidemiological study of sheep pox infection in Karnataka State, India. Rev Sci Tech. 2005;24:909-920. doi:10.20506/rst.24.3.1621

43. Hailat NO, Rawashdelt AL, Lafi S, AI-Batcinch Z. An outbreak of sheep pox associated with unusual Winter conditions in Jordan. Anim Heal Pro. 1994;23:79-80. doi:10.1007/BF02239903
Veterinary Medicine: Research and Reports is an international, peerreviewed, open access journal publishing original research, case reports, editorials, reviews and commentaries on all areas of veterinary medicine. The manuscript management system is completely online and includes a very quick and fair peer-review system. Visit http://www.dovepress.com/testimonials.php to read real quotes from published authors. 